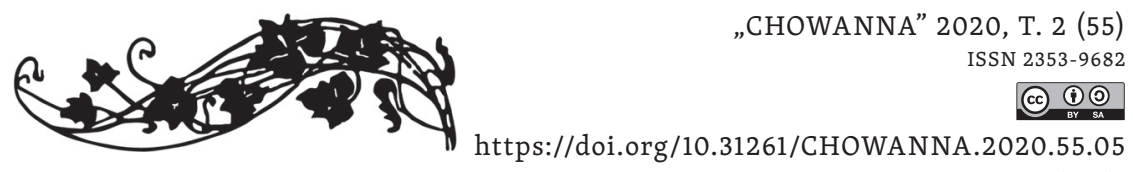

s. 1 z 13

\author{
Aleksandra Pyrzyk-Kuta \\ Uniwersytet Śląski w Katowicach \\ (iD https://orcid.org/0000-0001-6334-0991

\section{Niewypowiedziane naruszenia więzi i emocji, czyli o kryzysach zapisanych w ciele Znaczenie choreoterapii w redukcji napięć emocjonalnych}

\author{
Untold Violations of Bonds and Emotions; \\ or, on the Crises Registered in the Body \\ The Significance of Choreotherapy \\ for the Reduction of Emotional Tensions
}

Abstract: This article discusses bodily aspects of emotional crises and crises of interpersonal ties. The analysis is based on the sociological theory of emotions by Thomas J. Scheff and Suzanne Retzinger, who emphasized the importance of interpersonal ties for the resolution of conflicts and for successful coping with difficulties. Every emotion has its own motor equivalent in the body, which records and stores traumatic experiences and broadly understood conflicts together with the resulting stress. If the accumulated emotions are not released, the body may get sick, which is why psychological interventions must be combined with parallel work on the body. Case studies, which constitute an important part of the author's research, show the significance and effectiveness of choreotherapy, which, in combination with other treatment methods, helps to resolve crises and reduce emotional strain.

Keywords: emotions, emotional crisis, conflict, choreotherapy (dance and movement and dance therapy), interpersonal ties 


\section{Wprowadzenie}

Ciało jest jak piasek, umysł jest jak wiatr. Jeśli chcesz dowiedzieć się, jak wieje wiatr, popatrz na piasek.

Każdy człowiek jest indywidualnym bytem, determinowanym przez wiele czynników - od genetyki, przez środowisko rodzinne, przekaz kulturowy, po osobiste zdarzenia w ciągu życia. Fluktuacji wydarzeń oraz odpowiednim reakcjom na nie czasem może towarzyszyć brak gotowości na powstałą zmianę. Słowa Bonnie Bainbridge Cohen przytoczone jako motto podkreślają integralność ciała i emocji, zwracając uwagę na fakt, że ciało zawsze odzwierciedla aktualny stan naszego umysłu, może zatem ujawniać kryzysy emocji, chorobę, traumę, zerwane więzi, straty czy radości i ekscytację.

Alexander Lowen ${ }^{1}$ twierdził, że gdy trwamy w sytuacji kryzysowej, doświadczamy chronicznego napięcia mięśni, tracimy swobodę i grację. Wówczas należy podjąć interwencję na poziomie ciała. Takie nagromadzenie usztywniających i blokujących ciało napięć determinuje jakość funkcjonowania człowieka na poziomie społecznym, afektywnym i kognitywnym. Trajektorie losów zapisują się w naszej pamięci i pamięci ciała. Niektóre z nich silnie odzwierciedlają się w sposobie dalszego funkcjonowania. Emocje, których doświadczamy, są ograniczane i kanalizowane przez konteksty społeczno-kulturowe ${ }^{2}$. Konteksty aktywizują systemy ciała generujące emocje; najczęściej należą do nich złość i strach ${ }^{3}$, pojawiają się także wstyd i alienacja ${ }^{4}$. Długotrwałe kryzysy emocjonalne powodują zamrożenie energii i jej przepływu w ciele, uczucie skrępowania oraz zahamowanie ekspresji. Jednostka może przyglądać się temu w procesie głębokiej pracy nad sobą i pracy z ciałem z wykorzystaniem choreoterapii. Oba typy pracy mogą mieć wpływ na proces wewnętrznej zmiany.

${ }^{1}$ A. Lowen: Duchowość ciała. Warszawa 1991, s. 25.

${ }^{2}$ J.H. Turner, J.E. States: Socjologia emocji. Tłum. M. Bucholc. Warszawa 2009, s. 17.

${ }^{3}$ Ibidem, s. 18.

${ }^{4}$ S. Retzinger, T. Scheff: Emotion, Alienation, and Narratives: Resolving Intractable Conflict. „Mediation Quarterly” 2007, vol. 18 (1). https://doi.org/10.1002/ crq.3890180107. 


\section{Trudne emocje, konflikty i zachwiane więzi w koncepcji Thomasa J. Scheffa i Suzanne Retzinger}

Jak pisał Zygmunt Freud, „niewyrażone emocje nigdy nie umierają, zostają zakopane żywcem, aby powrócić w znacznie gorszej formie"s. Emocje odkładają się w ciele i blokują nie tylko jego ruch, lecz także komunikaty pozawerbalne, ograniczone zostają ekspresja mimiczna, kinestetyczna. Takie usztywnienie ciała, ekspresji może wynikać właśnie $\mathrm{z}$ istnienia nieprzepracowanych sytuacji, trudnych i zalegających spraw, które Suzanne Retzinger nazywa nierozwiązanymi konfliktami ${ }^{6}$. Przedłużający się konflikt może być konsekwencją separacji społeczno-emocjonalnej i niepotwierdzonego (nienazwanego) wstydu? Nierozwiązane konflikty wewnętrzne i narastające napięcia mogą grozić przerwaniem więzi społecznej. Zagrożenie więzi społecznej rozpadem wymaga permanentnej pracy nad jej budowaniem i wzmacnianiem, a także pracy nad emocjami - takiej, która zmienia i redefiniuje emocje "partnerów interakcji oraz podmiotu działającego, dając, chociażby chwilowe, poczucie wzajemnej akceptacji i bezpieczeństwa życia grupowego"8.

Wagę emocji w zawiązywaniu i podtrzymaniu więzi społecznej podkreślał Thomas J. Scheff'. Jako jeden z pierwszych socjologów zainteresował się problematyką emocji - zarówno jako komunikatów werbalnych, jak i pozawerbalnych, z uwzględnieniem kontekstu, w jakim komunikaty te występują ${ }^{10}$, to bowiem dzięki gestom wyrażamy uczucia i stany emocjonalne (przykładem są gesty miłosno-intymne, takie jak głaskanie, obejmowanie, tulenie, potęgujące słowny przekaz emocjonalny). Sygnały więzi społecznej zwykle przekazywane są pozawerbalnie ${ }^{11}$. Scheff pisał o wstydzie oraz alienacji, czyli odse-

${ }^{5}$ Z. Freud: Wstęp do psychoanalizy. Przeł. S. Kempnerówna, W. Zaniewicki. Warszawa 2015, s. 51.

${ }^{6}$ S. Retzinger, T. Scheff: Emotion, Alienation, and Narratives..., s. 71-85.

${ }^{7}$ S. Retzinger: Shame, Anger, and Conflict: Case Study of Emotional Violence. „Journal of Family Violence” 1991, vol. 6, no. 1. https://doi.org/10.1007/ BF00978525.

${ }^{8}$ K. Konecki, B. Pawłowska: W stronę socjologii emocji. „Przegląd Socjologii Jakościowej" 2013, T. 9, nr 2, s. 6. [Online:] http://www.qualitativesociologyreview.org/PL/Volume22/PSJ_9_2_Konecki_Pawlowska.pdf [dostęp: 10.12.2020].

9 T.J. Scheff: Emotions, the Social Bond, and Human Reality: Part/Whole Analysis. Cambridge 1997.

10 T.J. Scheff: Microsociology. Discurse, Emotion, and Social Structure. Chicago 1990, s. 87.

11 T.J. Scheff: Being Mentally Ill: A Sociological Theory. New York 1999, s. 145151. 
parowaniu i nietworzeniu związków z innymi, które postrzegał jako czynniki osłabiające więzi społeczne. Jednocześnie, wraz z Suzanne Retzinger, emocją wstydu tłumaczył wiele społecznych zjawisk i sytuacji, które właśnie przez wstyd są implikowane i nasilane.

Thomas J. Scheff i Suzanne Retzinger badali interakcje międzyludzkie podczas sesji psychoterapeutycznych, kłótni między partnerami, teleturniejów i sporów rozgrywających się na arenie politycznej. Stworzyli teorię, że źródłem destrukcyjnego konfliktu jest zaprzeczanie emocjom, wynikające $z$ odczuwanego przez jednostkę wstydu oraz jej poczucia osamotnienia i wyobcowania w związku ${ }^{12}$. Emocje i relacje, jak twierdzą ci socjolodzy, są z sobą zawsze ściśle powiązane. Wyalienowane relacje, jak piszą, osłabiają komunikację oraz generują intensywne emocje, zwłaszcza wstyd i złość ${ }^{13}$.

Do słownika terminów socjologicznych przez Thomasa J. Scheffa zostało wprowadzone pojęcie „pułapki uczuciowe” (feeling traps) ${ }^{14}$. Eksponuje ono swoistą gradację zjawiska doświadczania wstydu - ktoś raz zawstydzony może później czuć się zawstydzony tym, że się zawstydził. Takie zakłopotanie występuje w określonym kontekście podjętej interakcji. Swoje rozumienie pojęcia pułapek uczuciowych Scheff opierał na teorii psychoanalitycznej Helen Lewis ${ }^{15}$. Pisał też o chronicznym doznawaniu wstydu, który jest konsekwencją wystąpienia potrójnej spirali wstydu (triple spirals) i obejmuje wszystkie podmioty relacji ${ }^{16}$. Ten stan patologiczny mocno rzutuje na relacje międzyludzkie i więzi, może pogłębiać ich kryzys, a nawet doprowadzić do ich całkowitego przerwania. Odczuwany wstyd może uruchamiać inne emocje, takie jak złość, a nawet nienawiść, które również mogą przeradzać się i ewoluować w niekorzystne doznania i sytuacje. Nawarstwione silne emocje wywołują stres, co z kolei może mieć konsekwencje dla zdrowia somatycznego jednostki.

Gdy odczuwamy złość, lęk, strach, gniew i frustrację, warto przyjrzeć się źródłom tych emocji i postarać się przekuć je w konstruktywne jakości. Szansę na transformację emocji i autoekspresję stwarzają ruch i taniec. Próby pracy przez ruch i taniec można podjąć indywidualnie, w relacji z terapeutą lub w grupie. W sytuacjach kryzysowych jesteśmy bardziej skłonni wchodzić w związki interpersonalne, ponieważ potrzebujemy wówczas zrozumienia, wysłuchania, wsparcia,

\footnotetext{
12 T.J. Scheff, S. Retzinger: Emotions and Violence: Shame and Rage in Destructive Conflicts. Bloomington, Indiana 2020.

${ }^{13}$ S. Retzinger, T. Scheff: Emotion, Alienation, and Narratives..., s. 71-85.

14 T.J. Scheff: Microsociology..., s. 37-38.

15 Zob. ibidem, s. 38.

${ }^{16}$ Ibidem, s. 86.
} 
dotyku, utulenia ${ }^{17}$. Dla nierozwiązanych konfliktów antidotum może zawierać się w niedyrektywnym, humanistycznym podejściu, jakim jest terapia tańcem - choreoterapia.

\section{Taniec i ruch w aspekcie terapeutycznym}

Taniec w wielu kulturach ma szczególne znaczenie. Jest wyrazem religijnego zaangażowania i formą czczenia bogów, elementem wzmacniającym poczucie plemiennej tożsamości, sposobem komunikowania się. Współcześnie taniec postrzegany jest w wymiarze hedonistycznym, jako sposób przyjemnego spędzenia czasu oraz rozrywka związana z wysiłkiem fizycznym. Coraz częściej również w tańcu dostrzega się czynnik terapeutyczny i rozwoju osobistego. W literaturze polskiej dotyczącej alternatywnych metod wsparcia rozwoju mówi się najczęściej o choreoterapii, czyli terapii poprzez taniec i ekspresję ruchu $^{18}$.

Marion Hitzeler ${ }^{19}$ zauważa, że w bezpośrednim przeżywaniu relacji za pomocą ciała i podczas ruchowych doświadczeń powstają konflikty, które można odczuć na płaszczyźnie fizycznej. Dlatego tak ważna jest nauka obserwowania własnego ciała, wzmacnianie jego świadomości i świadomości ruchu. Świadoma praca z ciałem pozwala osiągnąć stan równowagi, nabyć zdolności regulowania napięć oddechem oraz zwracania uwagi na siebie, sytuację i otoczenie - „uwaga skierowana na ciało ma nie tylko obudzić wrażliwość i sprzyjać rozwojowi relacji

${ }^{17} \mathrm{~J}$. Hardison: Polepszanie związków interpersonalnych przez dotyk. W: Mosty zamiast murów. Podręcznik komunikacji interpersonalnej. Red. nauk. J. Stewart. [Tłum. J. Suchecki et al.]. Warszawa 2010, s. 141-143.

${ }^{18}$ Będę tu zamiennie używać pojęć „choreoterapia” i „terapia tańcem”. Stosowane w tym tekście nazewnictwo: „terapia tańcem” („choreoterapia”) i „psychoterapia tańcem i ruchem", wymaga wyjaśnienia i doprecyzowania. Te dwa określenia odsyłają do dwóch nurtów opartych na pracy z ciałem, wykorzystujących taniec i ruch. Różnice między nurtami wynikają przede wszystkim z kwalifikacji prowadzącego zajęcia ruchowe i sposobu kierowania procesem czy przebiegiem spotkań. Kwalifikacje te, normy i standardy są wypracowywane przez Polski Instytut Psychoterapii Tańcem i Ruchem w Warszawie oraz Polskie Stowarzyszenie Choreoterapii w Poznaniu, które ściśle współpracują z Amerykańskim Stowarzyszeniem Terapii Tańcem (ADTA).

${ }^{19}$ M. Hitzeler: Terapia przez taniec. W: T. Stegemann, M. Hitzeler, M. Blotevogel: Arteterapie dla dzieci i młodzieży. Muzykoterapia, choreoterapia, terapia sztuką. Słowo wstępne F. Resch, M. Schulte-Markwort. Uwagi wstępne H.H. Decker-Voight. Przekł. E. Cieślik. Gdańsk 2015, s. 81. 
z samym sobą, lecz także ujawnić, jak różne decydujące doświadczenia i formy obrony zdążyły się w nas zakorzenić"20.

Emocje odbijają się w naszym ciele - w postawie, gestach, ruchu i jego dynamice. Ciało uwikłane w dylematy, negatywne emocje i ich konsekwencje było przedmiotem analiz wybitnych psychoterapeutów: Wilhelma Reicha i Alexandra Lowena. Według Reicha, mechanizmy obronne uwydatniają się w postaci napięcia mięśniowego, które psychoterapeuta ten nazwał „zbroją ciała”"21. Reich prowadził obserwacje ciał pacjentów, szukał obszarów spięcia wywołanych skumulowaniem emocji lub tłumieniem emocji i psychologicznych treści ${ }^{22}$. Mawiał: „być w kontakcie to znaczy mieć świadomość własnego ciała, jego zamkniętości lub otwartości, istniejących napięć. Być w kontakcie to także zrozumieć, w jakim stopniu nasze doświadczenia ukształtowały osobowość na poziomie ciała"23.

Jak pisze Tomasz Rudowski ${ }^{24}$, emocje, uczucia i intelekt mają charakter transakcyjnych doznań zmysłowo-umysłowych, stanowią zarówno o wzbudzeniu, jak i przebiegu procesu tworzenia, w tym stwarzania siebie i budowania swojej tożsamości. Doznania transakcyjne łączą się z procesami percepcji i kreacji, które generują nowe wartości artystyczno-estetyczne oraz nowe kompetencje indywidualne. Rudowski zauważa, że podczas arteterapii (w której ramach lokowana jest także choreoterapia) terapeuta może zaobserwować, jak środki wyrazu wpływają na przeżycia ich twórcy (uczestnika sesji arteterapeutycznej), ale też przyjrzeć się przeżyciom jednostki determinowanym różnymi jej dysfunkcjami i przeanalizować wybór środków artystyczno-estetycznych sprzyjających redukowaniu tych dysfunkcji ${ }^{25}$. Podczas spotkań choreoterapeutycznych obserwuje się, jak uczestnicy reagują na bodźce dźwiękowe, czuciowe, wizualne, jak zachowują się w kontaktach interpersonalnych, w trakcie wymiany i doznawania ruchów.

Aby odkrywanie, wyrażanie i definiowanie swojego Ja, także w kreacji ruchowej, mogło służyć uczestnikowi procesu terapeutycznego, muszą być spełnione pewne warunki uruchamiające wewnętrzną prze-

${ }^{20}$ T. Stegemann: Muzykoterapia. W: T. Stegemann, M. Hitzeler, M. Blotevogel: Arteterapie dla dzieci i młodzieży..., s. 64.

${ }^{21}$ Podaję za: Z. Pędzich: Psychoterapia tańcem i ruchem $w$ Polsce i na świecie. W: Psychoterapia tańcem i ruchem. [T.] 1: Teoria i praktyka. [1]. Red. Z. Pędzich. Sopot 2014, s. 26.

${ }^{22}$ Podaję za: ibidem.

${ }^{23}$ Cyt. za: ibidem, s. 38.

${ }^{24}$ T. Rudowski: Edukacja i terapia przez sztukę. Arteterapia w świetle doznań transakcyjnych. Warszawa 2013, s. 45.

${ }^{25}$ Ibidem, s. 92. 
mianę i rozwój, czyli czynniki leczące ${ }^{26}$. Najważniejszym z nich, jak pisze Czesław Czabała, są kontakt i relacja terapeutyczna ${ }^{27}$. To właśnie relacja, w diadzie: pacjent - terapeuta, sprawia, że działanie tańcem ma wymiar terapeutyczny, nadaje wsparciu inny sens, nie wymaga słów, lecz pozwala jednostce się wypowiedzieć, wyrazić. Elementarne czynniki w terapii, które mogą przyczynić się do zmiany Ja, wymienił Irvin Yalom ${ }^{28}$, a należą do nich: a) zaszczepianie nadziei, b) uniwersalność, c) udzielanie informacji, d) altruizm, e) korektywna rekapitulacja pierwotnej grupy rodzinnej, f) rozwój umiejętności społecznych, g) naśladowanie, h) interpersonalne uczenie się, i) wspólnotowość, j) katharsis, k) czynniki egzystencjalne. Do tego zestawu należy dodać inne rudymentarne czynniki leczące wskazane przez Abrahama Maslowa ${ }^{29}$ : a) bezpieczeństwo, b) miłość, c) poczucie przynależności, d) poczucie własnej wartości i e) szacunek do samego siebie.

\section{Z praktyki choreoterapeutycznej - studia przypadków}

Praktyka terapii tańcem ukazała mi klarowność i istotność czynników leczących w choreoterapii. W pracy z małymi grupami dostrzegam powiązanie między wymienionymi czynnikami, które niemal wzajemnie się warunkują. Na przykład jeśli uczestnik ma na coś nadzieję, oczekuje czegoś, co wyznacza obszar jego spełnienia, wówczas jest w stanie o to zawalczyć, podjąć ryzyko, a zachętą jest życzliwość grupy, mobilizowanie przez nią, jej spójność. Swoje marzenia i pragnienia uczestnik wizualizuje w tańcu i ruchu, uaktywnia swoje projekcje w przestrzeni dzielonej z innymi. Najbardziej nośnym czynnikiem leczącym jest jednak nadawanie osobistego znaczenia - sprawia to, że uczestnicy zajęć uświadamiają sobie, co się wydarza i w jaki sposób im to służy.

Studium przypadków to swoisty katalog mających swą reprezentację w ciele emocji uczestników prowadzonych przeze mnie terapii tańcem. Długo niewyrażone emocje zamrażały ciało i nawet jeśli nie były pamiętane, tkwiły w pamięci mięśniowej ${ }^{30}$. Każda z opisywanych osób

${ }^{26}$ C. Czabała: Czynniki leczące w psychoterapii. Wyd. 4. zm., dodruk. Warszawa 2008, s. 64.

${ }^{27}$ Ibidem.

${ }^{28}$ I. Yalom, M. Leszcz: Psychoterapia grupowa. Teoria i praktyka. Tłum. R. Andruszko. Kraków 2006, s. 10.

29 A. Maslow: Motywacja i osobowość. Wyd. 2, dodr. 2. Warszawa 2013, s. 167.

${ }^{30}$ Z. Pędzich: „Oswoić cień”. Psychoterapia tańcem $i$ ruchem $w$ pracy nad $w y$ chodzeniem z depresji i przygotowania do macierzyństwa. W: Psychoterapia tańcem i ruchem. [T.] 1: Teoria i praktyka..., s. 336. 
uczestniczyła w odmiennych spotkaniach choreoterapeutycznych. Elementem wiążącym wszystkie przypadki są przykre doświadczenia uczestników oraz ich trudność w zwerbalizowaniu emocji, które sprzęgają się z naruszeniem więzi rodzinnych, przerwaniem ciągłości relacji i załamaniem kondycji psychofizycznej. Taniec i ruch zastosowano po to, by uruchomić wgląd w siebie i indywidualną ekspresję uczestników, a tym samym umożliwić im przepracowanie nagromadzonych doświadczeń. Opisana wcześniej socjologiczna koncepcja emocji autorstwa Thomasa J. Scheffa i Suzanne Retzinger dotycząca poczucia wstydu, który może być generatorem konfliktów i czynnikiem dezintegrującym w relacjach, jest rzadko przywoływana, ale bardzo dobrze objaśnia i tłumaczy powstawanie pewnych mechanizmów opisanych w przytoczonych studiach przypadków.

\section{Ksenia, lat 28}

Ksenia była uczestniczką grupy wsparcia dla kobiet współuzależnionych. Od wielu lat pozostawała w związku z mężczyzną uzależnionym od alkoholu, dopuszczającym się przemocy fizycznej i emocjonalnej. Ksenia chciała zrozumieć przebieg tej relacji i przeanalizować więzi łączące ją z partnerem. W tym celu podjęła psychoterapię grupową. Do zajęć terapeutycznych w tej grupie dodano czynnik choreoterapii, która miała być buforem dla nieuświadomionych emocji. Początkowo Ksenia zdawała się akceptować obowiązujący regulamin, w tym jedną z jego reguł, mianowicie „pozostawanie w wierności sobie”. W aktach werbalizacji sygnalizowała komfort i satysfakcję, jej ciało jednak (skrzyżowane ręce na klatce piersiowej i skrzyżowane nogi) zdradzało odmienne uczucia. Na pytanie terapeutki dotyczące rzeczywistego samopoczucia Ksenia stanowczo zaprzeczyła, że jej słowa są niezgodne z prawdziwymi uczuciami.

Sesja z wykorzystaniem tańca i ruchu umożliwiła uczestnikom pracę $\mathrm{z}$ ich granicami, a tym samym emocjami i więziami. Podczas tej sesji obserwowano, jak kobieta sztywniała przy każdym ruchu mającym na celu zatrzymanie tanecznego partnera (odgrywał on partnera życiowego Kseni). Nieustannie dostrzegalne były zaprzeczenie i złość połączona z reakcjami fizjologicznymi (rumieńce, nadmierna potliwość). Uwidaczniało się zawstydzenie, o którym świadczył wzrok wbity w podłogę, a także zgarbione plecy przypominające pancerz. Terapeutki odnosiły wrażenie, że ciało Kseni jest napięte od dużej ilości negatywnych i przetrzymanych emocji. Finalnym akcentem tego spotkania była struktura "taniec $\mathrm{z}$ aniołem”. Metafora anioła jako osoby ochraniającej, czułej, troskliwej, kochającej spowodowała lawinę dotąd 
skrywanych wewnętrznych konfliktów i nienazwanych emocji. Toksyczna relacja i pozorność więzi przykryte zostały emocjami kobiety: pragnieniem miłości, bycia ważną i potrzebną. Pragnienia te zafałszowały realny stan relacji. Nastąpił moment katharsis - kobieta została zalana silnymi wspomnieniami, emocjami wprowadzającymi ciało w drgania, zaszlochała. Taniec pozwolił na oczyszczenie i uwolnienie od negatywnych myśli i zdarzeń, zadziałał katarktycznie i umożliwił inne spojrzenie na trwającą od lat sytuację. Ksenia uświadomiła sobie swoje pragnienia, marzenia, a przede odzyskała utracone Ja. Ucieleśnienie wspomnianej relacji i uświadomienie sobie przez kobietę jej "zagubienia i rezygnacji z siebie” dały Kseni impuls do nowej drogi i pracy nad sobą. Ruch otworzył dostęp do nieuświadamianych treści ${ }^{31}$, pojawiła się tęsknota za stabilną więzią, prawdziwymi emocjami i szacunkiem.

\section{Konrad, lat 20}

Konrad był podopiecznym ośrodka leczenia uzależnień - w którym w ramach działań terapeutycznych zorganizowano warsztaty rozwojowe o charakterze choreoterapii - uzależnionym od środków psychoaktywnych. Eksperymentację narkotyczną rozpoczął, gdy miał 14 lat. Miał to być sposób chłopaka na zapomnienie o domu bez miłości, z wyzwiskami, niedostatkiem środków do życia i o udręczającym poczuciu wstydu. Młody mężczyzna pochodził z małej miejscowości, w której wszyscy mieszkańcy dobrze się znają. Jego rodzina i znajomi zauważyli, że często znajduje się w kryzysowych sytuacjach. Narkotyki dawały Konradowi iluzoryczne poczucie mocy i inności, ukojenie, a jednocześnie powodowały utratę więzi z przyjaciółmi, wycofanie się z kontaktów z rówieśnikami i zaniechanie realizacji obowiązków szkolnych.

Konrad był małomówny, sprawiał wrażenie obojętnego, chociaż dostrzegalne było to, że odczuwał dużą potrzebę kontroli. Miał zdolności manualne - pięknie rysował, bardzo sprawnie posługiwał się narzędziami i majsterkował (naprawiał występujące w ośrodku usterki). Podczas początkowych sesji terapii tańcem Konrad kwestionował zasadność zajęć, z góry zakładał, że niczego nie wniosą one w jego życie. Zawsze tańczył sam do zadanego tematu, unikał połączeń, nie zabierał też głosu w rundach powitalnych ani finalnych. Obserwowano silną alienację emocjonalną chłopaka, jego potrzebę odcięcia się, odgrodzenia od zbiorowości. Ciało Konrada przypominało zbroję, spod której wyłaniały się pustka i lęk. Zadaniem takiej mięśniowej zbroi jest unie-

${ }^{31}$ Ibidem. 
ruchomienie jednostki i chronienie jej przed tym, co na zewnątrz ${ }^{32}$. Ta symboliczna zbroja służyła temu, by Konrad mógł nie czuć - nie odczuwać bólu, zawiedzionych nadziei, wstydu za samego siebie, za rodziców. Chłopak chciał, by nikt już go nie zranił, nie nasilał jego poczucia kryzysu i swego rodzaju nicości. Podczas zajęć poruszał się w wąskiej kinesferze, często siadał na podłodze. Wieloletnie zażywanie przez Konrada środków psychoaktywnych zmieniło także jego zdolność percepcji oraz nazywania uczuć i emocji. Aby wyrazić słownie swoje odczucia, Konrad musiał odwoływać się do wiszącego na ścianie spisu emocji, które człowiek może odczuwać, uczył się - ab ovo - sprawdzania, czy to, co odczuwa, jest właśnie tym stanem emocjonalnym.

Przełomowym momentem terapii było spotkanie, w trakcie którego Konrad zabrał głos jako pierwszy. Poruszone - po cielesnych doświadczeniach do muzyki - ciało stworzyło przestrzeń do skanalizowania tłumionych i uwięzionych reakcji emocjonalnych. Konrad nabył świadomości tego, co go ogranicza. Jego wypowiedź zdradzała pewną gradację doświadczania wstydu (opisaną przez Scheffa w jego teorii) ${ }^{33}$. Konrad mówił o negatywnej ocenie siebie, odczuwanym wstydzie, który pogłębiany był tym, jak chłopaka oceniali jego bliscy, co w rezultacie przyczyniło się do poczucia odrzucenia. Ta kompilacja odczuć Konrada doprowadziła zarówno do jego alienacji, jak i do naruszenia więzi, pewnej deprywacji emocjonalnej. Konrad odrzucał też taneczną relację z innymi, rezygnował z łączenia się w pary, patrzenia w oczy, kontaktu w bliskim dystansie proksemicznym. Te autorefleksje przyniósł mu ruch, ale też zatrzymanie się, które poruszyło retrospekcję i obudziło emocje. Po dziesięciu sesjach (spotkania miały formułę krótkoterminową) mężczyzna stanął z innymi w kręgu. Zatańczył z pozostałymi uczestnikami i, jak później skomentował, „poczuł oswobodzenie”. Być może te spotkania Konrada z sobą samym w tańcu i ruchu przyniosą zrozumienie innych, otwarcie się na nową przyszłość wolną od uzależnień, wypełnioną świadomymi wyborami, dumą z siebie i samozadowoleniem.

\section{Janina, lat 32}

Janina to matka dwojga dzieci z głęboką obustronną głuchotą czuciowo-nerwową, po wszczepach implantów ślimakowych. Jedno z dzieci ma wiele sprzężeń, w tym niedowidzenie i epilepsję, nie porusza się samo-

${ }^{32}$ M. Barszcz: Psychoterapia przez ciało. Współczesna analiza bioenergetyczna przez ciało. Warszawa 2018, s. 55.

${ }^{33}$ T.J. Scheff: Microsociology..., s. 87. 
dzielnie. Janina uczestniczyła w warsztatach choreoterapeutycznych dla rodziców, które wpisane były w ofertę turnusu rehabilitacyjnego dla dzieci. W rundach inicjalnych głośno i z uśmiechem sygnalizowała pragnienie wytchnienia, czasu dla siebie, relaksu. Pogodna, radosna, ze skłonnością do zawłaszczania przestrzeni i szybkiego przemieszczania się po parkiecie. W toku jednej z sesji z zaciekawieniem wsłuchiwała się w opis struktury - była to „walka o wartości”, taniec wykonywany w podgrupach, który miał zilustrować, jakie idee i wartości uznają uczestniczki sesji, co jest im bliskie, czemu lub komu przypisują całkowite oddanie i poświęcenie. Janina poruszała się szybko, jej głowa jednak zwieszona była w dół, przygarbione ramiona tworzyły swego rodzaju „półeczkę”, miała podwiniętą miednicę i podkurczone nogi. Alexander Lowen nazywa taką postawę "hakiem" ${ }^{34}$. Tańczyła sama, ale też kooperowała $\mathrm{z}$ innymi i partnerowała im. W rundzie werbalizacji długo milczała, jej postawa ciała mówiła o potrzebie ukrycia się, siedziała skulona. Lowen interpretował to jako odpowiedź na lęk i podporządkowanie, chęć kontroli impulsów zawartą w ciele, które głosi: „dźwigam świat na swoich ramionach" ${ }^{35}$. Janina w swojej narracji potwierdziła poczucie przeciążenia, niemocy, lęku o przyszłość swoich dzieci, ich rehabilitację, nabywanie przez nie umiejętności, a także osamotnienia $\mathrm{w}$ walce o ich dobro. $\mathrm{W}$ tym heroicznym zmaganiu była sama, mąż zajęty był pracą i zdobywaniem finansów na utrzymanie domu. Ta samotność $\mathrm{w}$ działaniu, pojawiające się poczucie wstydu z powodu nawarstwionego zmęczenia zostały wyrażone i dostrzeżone w tańcu kobiety. Odczuwana kryzysowość uległa przeobrażeniu w siłę i sprawczość. Janina poczuła, że musi i ma prawo prosić męża o pomoc, że musi zadbać o siebie, swoje emocje, zdrowie i urodę. Otrzymała ogromne wsparcie informacyjne i emocjonalne od pozostałych uczestniczek sesji. Była wzruszona, że inne kobiety są w stanie wymienić wiele jej pozytywnych cech, komplementować ją. W domykającym spotkanie tańcu w kręgu wzruszenie Janiny nie ustępowało, niosło też ukojenie i oczyszczenie z nagromadzonych, przytłaczających emocji. Kolejne ruchy tej kobiety w tańcu były już spokojne, ale wyrażały postawę świadomej siebie wojowniczki, która w walce o innych i dla innych nie zapomina o sobie samej.

${ }^{34}$ A. Lowen: Duchowość ciała..., s. 95.

${ }^{35}$ M. Barszcz: Psychoterapia przez ciało..., s. 34. 


\section{Podsumowanie}

Opisy wszystkich przytoczonych przypadków wskazują, że doznane kryzysy emocjonalne i kryzysy więzi oraz wykształcone - pod ich wpływem - lub powielane reakcje obronne organizmu są prawdziwym więzieniem dla witalności jednostki ${ }^{36}$. Lekarstwem dla Kseni, Konrada i Janiny okazał się taniec, ruch i poczucie wspólnoty. Terapia tańcem ukazuje obszary pracy człowieka nad nim samym, pozwala na skanalizowanie emocji, a przede wszystkim wzbogaca wiedzę jednostki o niej samej i wpływa na koherentny odbiór życia i doświadczeń. Abraham Maslow mówił, że doświadczenie trudnej sytuacji nie musi być zagrażające - jeżeli dobrze sobie z nią radzimy, może być nawet wzmacniające i pouczające ${ }^{37}$. Takie konstruktywne myślenie wznieca nowe siły.

Zdaniem Zuzanny Pędzich ${ }^{38}$ ruchowe eksploracje pozwalają jednostce na odkrycie jej mocnych i słabych stron, są okazją do poszukiwania preferencji ruchowych i alternatywnych sposobów bycia. Pogłębiony taniec i ruch może pomóc zmniejszyć samokrytycyzm, zredukować opór i lęk. Swobodne wyrażanie swoich myśli nieskalanych wstydem, ekspresja emocji bez ich tłumienia oraz obawy, że zostaną wyśmiane przez innych, są istotnymi aspektami samorealizowania się człowie$\mathrm{ka}^{39}$. Maslow zaznaczał, że osoby samorealizujące się są w stanie utworzyć głębsze relacje interpersonalne, są zdolne do silniejszych więzi, do większej miłości oraz doskonalszej identyfikacji uczuć i emocji ${ }^{40}$. Niezbędnym i nieocenionym czynnikiem facylitującym proces terapeutyczny w sytuacji kryzysowej oraz na drodze do autokreacji oraz samorealizacji jednostki są osoby, z którymi jest ona związana. Pozostawanie w autentycznej, zaangażowanej relacji umożliwia przezwyciężenie trudności i zmierzenie się z nową sytuacją oraz wynikającymi z niej doświadczeniami.

\section{Bibliografia}

Barszcz M.: Psychoterapia przez ciało. Współczesna analiza bioenergetyczna przez ciało. Warszawa 2018.

Czabała C.: Czynniki leczące w psychoterapii. Wyd. 4. zm., dodruk. Warszawa 2008.

\footnotetext{
${ }^{36}$ Ibidem, s. 93.

${ }^{37}$ A. Maslow: Motywacja i osobowość..., s. 143.

38 Z. Pędzich: „Oswoić cień”..., s. 341.

${ }^{39}$ A. Maslow: Motywacja i osobowość..., s. 250.

${ }^{40}$ Ibidem, s. 222.
} 
Freud Z.: Wstęp do psychoanalizy. Przeł. S. Kempnerówna, W. Zaniewicki. Warszawa 2015.

Hardison J.: Polepszanie związków interpersonalnych przez dotyk. W: Mosty zamiast murów. Podręcznik komunikacji interpersonalnej. Red. nauk. J. Stewart. [Tłum. J. Suchecki et al.]. Wyd. 4, dodr. 4. Warszawa 2010.

Konecki K., Pawłowska B.: W stronę socjologii emocji. „Przegląd Socjologii Jakościowej" 2013, T. 9, nr 2. [Online:] http://www.qualitativesociologyreview.org/PL/Volume22/PSJ_9_2_Konecki_Pawlowska.pdf [dostęp: 10.12.2020].

Lowen A.: Duchowość ciała. Warszawa 1991.

Maslow A.: Motywacja i osobowość. Wyd. 2, dodr. 2. Warszawa 2013.

Psychoterapia tańcem i ruchem. [T.] 1: Teoria i praktyka. [1]. Red. Z. Pędzich. Sopot 2014.

Retzinger S.: Shame, Anger, and Conflict: Case Study of Emotional Violence. „Journal of Family Violence" 1991, vol. 6, no. 1. https://doi/org/10.1007/ BF00978525.

Retzinger S., Scheff T.: Emotion, Alienation, and Narratives: Resolving Intractable Conflict. „Mediation Quarterly” 2007, vol. 18 (1). https://doi. org/10.1002/crq.3890180107.

Rudowski T.: Edukacja i terapia przez sztukę. Arteterapia $w$ świetle teorii doznań transakcyjnych. Warszawa 2013.

Scheff T.J.: Being Mentally Ill: A Sociological Theory. New York 1999.

Scheff T.J.: Emotions, the Social Bond, and Human Reality: Part/Whole Analysis. Cambridge 1997.

Scheff T.J.: Microsociology. Discourse, Emotion, and Social Structure. Chicago 1990.

Scheff T.J., Retzinger S.: Emotions and Violence: Shame and Rage in Destructive Conflicts. Bloomington, Indiana 2020.

Stegemann T., Hitzeler M., Blotevogel M.: Arteterapie dla dzieci i młodzieży. Muzykoterapia, choreoterapia, terapia sztuką. Słowo wstępne F. Resch, M. Schulte-Markwort. Uwagi wstępne H.H. Decker-Voight. Przekł. E. Cieślik. Gdańsk 2015.

Turner J.H., States J.E.: Socjologia emocji. Tłum. M. Bucholc. Warszawa 2009.

Yalom I., Leszcz M.: Psychoterapia grupowa. Teoria i praktyka. Tłum. R. Andruszko. Kraków 2006. 